Canadian University Music Review

Revue de musique des universités canadiennes

\title{
Heinrich Schütz's Musikalische Exequien: Evidence of Influence
}

\section{Gregory S. Johnston}

Numéro 13, 1993

URI : https://id.erudit.org/iderudit/1014293ar

DOI : https://doi.org/10.7202/1014293ar

Aller au sommaire du numéro

\section{Éditeur(s)}

Canadian University Music Society / Société de musique des universités canadiennes

\section{ISSN}

0710-0353 (imprimé)

2291-2436 (numérique)

Découvrir la revue

Citer cet article

Johnston, G. S. (1993). Heinrich Schütz's Musikalische Exequien: Evidence of Influence. Canadian University Music Review / Revue de musique des universités canadiennes, (13), 1-14. https://doi.org/10.7202/1014293ar
Résumé de l'article

Heinrich Schütz's Musikalische Exequien (SWV 279-81), written for the funeral of Prince Heinrich Posthumus von Reuß in 1636, is generally regarded as one of his finest works. Oddly, though, the praise accorded the composition has come almost entirely from critics of the last fifty years, while it is thought to have had negligible resonance in the seventeenth century. The present article suggests that the Exequien may in fact have been used as a model for three compositions by Michael Wiedemann in 1693. Based on comparisons of the circumstances which occasioned the works, on the identification of numerous shared compositional processes exclusive to these works in the seventeenth-century funerary repertory, on certain professional motivations, and on the logistics of publishing and geography which would have made the Exequien available to Wiedemann, it becomes possible to suggest with reason that Schütz's Musikalische Exequien was not without influence in baroque Germany.
All Rights Reserved (C Canadian University Music Society / Société de musique des universités canadiennes, 1993
Ce document est protégé par la loi sur le droit d'auteur. L’utilisation des services d'Érudit (y compris la reproduction) est assujettie à sa politique d'utilisation que vous pouvez consulter en ligne.

https://apropos.erudit.org/fr/usagers/politique-dutilisation/ 


\title{
HEINRICH SCHÜTZ'S MUSIKALISCHE EXEQUIEN: EVIDENCE OF INFLUENCE*
}

\author{
Gregory S. Johnston
}

It is generally agreed that Heinrich Schütz's Musikalische Exequien (SWV 27981 ) is among the most inspired of all his works. Schütz himself thought highly enough of the Exequien that he had it published in 1636, and later assigned to it an opus number (op. 7), ${ }^{1}$ a distinction he reserved for his most valued creations and attributed only once to an ad hoc composition. Ironically, though, the praise accorded Schütz's Exequien has come almost entirely from writers of this century, while in the seventeenth, as Werner Breig observes in a recent article, "Schütz's attempt to detach the work from its original purpose apparently found little resonance among his contemporaries ..."2 Did Schütz at the height of his career completely misjudge contemporary tastes, or have we perhaps underestimated the importance of the Musikalische Exequien to Lutheran musicians of the seventeenth century?

Although there are no surviving prints of the complete work (which in itself bespeaks a modest publishing run), the Musikalische Exequien did not simply disappear without leaving some impression on German musicians of the seventeenth century. A surviving manuscript copy of the continuo part currently housed in the Biblioteka Gdanská suggests that at least the third movement was

* Versions of this article were presented in 1990 at the Annual Meeting of the Pacific Northwest Chapter of the American Musicological Society at the University of Washington (Seattle), and at the Annual Meeting of the Canadian University Music Society at the University of Victoria (Victoria). I am grateful to Timothy J. McGee for his comments and suggestions on an earlier draft of this article.

1 Schütz's catalogue of works with opus numbers appears on the last page of the Bassus pro Violone partbook of the Symphoniae sacrae II. See H. Schütz, Symphoniae Sacrae II/1647, 3 Vols., ed. W. Bittinger, Neue Ausgabe sämtlicher Werke (Kassel: Bärenreiter, 1:1964; 2:1965; 3: 1968), 2:xv. Facsimile reprints, Ibid., xxiii; and O. Brodde, Heinrich Schütz: Weg und Werk (Kassel: Bäreneiter-Verlag, 1972; Berlin: Evangelische Verlagsanstalt, 1985), 194.

2 W. Breig, "Heinrich Schütz's Musikalische Exequien: Reflections on Its History and TextualMusical Conception," in Church, Stage, and Studio: Music and Its Contexts in SeventeenthCentury Germany, ed. P. Walker, Studies in Music, no. 107 (Ann Arbor: U.M.I. Research Press, 1990), 123. Breig's article was previously published as "Heinrich Schütz's Musikalische Exequien: Überlegungen zur Werkgeschichte und zur textlich-musikalischen Konzeption," Schütz-Jahrbuch 11 (1989): 53-68. 
performed sometime in the seventeenth century. ${ }^{3}$ Some if not all of the work was also heard at a funeral in 1645 , evidenced by a surviving intabulation made of the first two movements by Johannes Šimbracký, organist in Kirchdorf, Waralia (currently Spisšké Podhradie, Slovak Republic) from 1630 to $1657 .{ }^{4}$ There is, moreover, the possibility of the Musikalische Exequien's sphere of influence extending beyond transcriptions and performances of it during Schütz's lifetime. I would like to suggest in this study that the Exequien, in keeping with the Baroque tradition of musico-rhetorical imitatio, may in fact have been used posthumously as a model for another composer's work - namely, Michael Wiedemann's music composed for the funeral in 1693 of Sigismund Heinrich, Baron of Bibran and Modlau.

Before examining these works together, it may prove useful at the outset to sketch in some of the background to the composers and the compositions in question. As regards Heinrich Schütz, who in 1636 was Hofkapellmeister in Dresden and Royal Danish Kapellmeister in Copenhagen, he is generally considered to be the most significant German composer of the seventeenth century - a view shared equally by Schütz's contemporaries. The three works comprising the Musikalische Exequien were composed by Schütz for the funeral in February 1636 of his sovereign Prince Heinrich Posthumus von Reuß (15721635). Throughout his life. Heinrich Posthumus was well-known for his diplomatic skills, as a generous patron of the Church, education and the arts, and also as a proficient instrumentalist and singer. His long personal and professional association with Schütz began as early as 1617 , at which time the Prince entrusted Schuitz with the reorganization of the musical affairs of the court,

3 Ms. Danzig. Biblioteka Gdanská Polskiej Akademii Nauk, Ms. 4012 Nr. 5b, Nr. 67. Graulich, xviii (English trans., xxxiv). Facsimile reprint in G. Graulich, "Kritischer Bericht", Musikalische Exequien, op. 7, by Heinrich Schütz, Stuttgarter Schütz-Ausgabe, v. 8 (Neuhausen-Stuttgart: Hänssler-Verlag, 1973), 1xi.

4 Ms. Levoča. Levoča, Ev. far. kostol sign. 13.993. This manuscript is currently located in the music collection of the former Protestant college in Levoča (formerly Leutschau), Slovak Republic, approximately 15 kilometres west of Spiš̌ké Podhradie. Graulich, "Kritischer Bericht," xviii (Engl. trans., xxxiv). Facsimile reprint, ibid., lxi. For additional information about Šimbracký, see R. Rybaric, "Johannes Šimbracký und die Zipser Musikkultur des 17. Jahrhunderts," Sagittarius 2 (1960): 63-6.

5 The actual ties between the Schütz and Reuß families date back at least another two years, at which time Schütz's brother, Georg (1583-1637), was installed as tutor to Heinrich Posthumus's sons. See H. R. Jung, "Ein neuaufgefundenes Gutachten von Heinrich Schütz aus dem Jahre 1617," Archiv für Musikwissenschaft 18 (1961): 241-47; and H. R. Jung, "Ein unbekanntes Gutachten von Heinrich Schütz über die Neuordnung der Hof-, Schul- und Stadtmusik in Gera," Beiträge zur Musikwissenschaft 4, no. 1 (1962): 17-36. For additional information on Schütz's familial ties to Gera, see E. P. Kretschmer, "Schütz in Gera," in Festschrift zur Ehrung von Heinrich Schütz, ed. G. Kraft (Weimar: Buchdruckerei Uschmann, 1954): 57-60. 
school and town of Gera. ${ }^{6}$ Perhaps the most striking detail about Heinrich Posthumus in view of the Musikalische Exequien is that the entire first movement of the work is based almost entirely on the Prince's own selection of scriptural and chorale texts which he secretly had inscribed on his coffin a year before his death.

In contrast to Schütz, rather little is known about the second composer, Michael Wiedemann. Born of peasant stock in Upper Lusatia in 1659, he was employed as pastor in Ossig near Liegnitz (currently Legnica, Poland) and subsequently at Schweidnitz (currently Swidnica, Poland). ${ }^{6}$ Better known for his literary than his musical production, Wiedemann was author of an invidious collection entitled Historisch-poetischer Gefangenschaften, published at Leipzig in 1689 and $1690 .^{7}$ Because of the calumnies against the Catholic Church perceived in these and perhaps other works by Wiedemann, the Jesuits conspired towards and eventually succeeded in having him expelled from his pastoral post. In 1702, he was appointed Superintendent by the Count of Stolberg-Wernigerode, where he also served in the capacity of senior and court preacher (Ober- und Hofprediger). Wiedemann died at Stolberg on 1 September 1719.

Sigismund Heinrich, Baron of Bibran and Modlau, for whom Wiedemann's three pieces were composed, was born 26 February $1640 .{ }^{8}$ Although there is little record of his earliest years, it is known that he spent a five-year period, most likely in the mid 1660s, travelling throughout western Europe, immersing himself in foreign customs and languages in preparation for his accession to the baronetcy. He married in 1669 , subsequently fathered eighteen children, and at last, after a brief illness, passed away at the age of fifty-three on 14 September 1693 , survived by two sons, four daughters and his wife of twenty-four years.

6 The biographical information on Michael Wiedemann is taken from the following sources: E. L. Gerber, Historisch-biographisches Lexikon der Tonkünstler (1790-1792), 2 vols., facs. repr. ed. O. Wessely (Leipzig, 1790; Graz: Akademische Druck-u. Verlagsanstalt), 1: col. 804; C. F. Becker, Systematisch-chronologische Darstellung der musikalischen Literatur von der frühesten bis auf die neueste Zeit (Leipzig: Robert Friese, 1836; Amsterdam: Frits A. M. Knuf, 1964), col. 502; and R. Eitner, Biographisch-bibliographisches Quellen Lexikon, 11 vols. in 6 (Graz: Akademische Druck-u. Verlagsanstalt, 1959), 10:255.

7 Wiedemann's Historisch-poetischer Gefangenschafften were published as a series, at least some of them known to contain music. According to Eitner, twelve different issues were published between January and December, 1690. Two issues from the previous year are cited in RISM: Historisch-poetischer Gefangenschafften 5. Monat Majus, fürstellend einen schwermüthigen oder bekümmerten Studenten Namens Theophorus [RISM W1051] (Leipzig: Reinhard Wächtler, 1689), and Historisch-poetischer Gefangenschafften sechster Monat Junius, fürstellend den unbesorgten Musicanten Namens Fido [RISM W1052] (Leipzig: Reinhard Wächtlers Witwe, 1689.

8 Biographical information for Sigismund Heinrich is derived entirely from the Lebenslauf which was published with the other parts of the Leichenpredigt in 1695. 
Sigismund Heinrich's funeral was held almost three months later on 9 December. In the case of both Sigismund Heinrich and Heinrich Posthumus, it was in the course of the second of two funerary ceremonies that the principal commissioned music was performed. Aside from noticeable similarities of the circumstances that occasioned these works - both being commissioned for and performed at the concluding ceremonies of the funerals for the heads of two aristocratic and staunchly Lutheran households - the first salient compositional similarity one will notice is that both works are conceived in three discrete parts. Of the approximately seven hundred entries for printed funeral music of the seventeenth century listed in RISM's Einzeldrücke vor 1800 and in Wolfgang Reich's Threnodiae Sacrae, remarkably few, less than two percent of the total number of entries, identify groups of three ad hoc pieces by a single composer. In fact, the vast majority of composers of occasional music published in seventeenth-century Germany never wrote more than a single work for a funeral. A few, like Paul Hainlein of Nuremberg, regularly wrote pairs, but ad hoc funerary compositions in groups of three appeared only rarely. Schütz's and Wiedemann's works can be seen to belong to an even more exclusive group when one considers that, of the known funerary works published in groups of three, almost half were written by the Nuremburg organist, Heinrich Schwemmer. ${ }^{9}$

Also noteworthy about these two works is the placement of the discrete parts within the funeral ceremony, the first item performed prior to the sermon, the second and third at the conclusion of the service. The opening work of the Musikalische Exequien, described by Schütz as a "Concert in the form of a German funeral mass" (Concert in Form einer deutschen Begräbnis-Missa), is in many respects a work sui generis; it is exceptional in the literature in that it served liturgically at the opening of the service as an elided Introit and quasiMissa brevis. Because the text, form, and liturgical function of this work were determined almost entirely by Heinrich Posthumus and were thus closely identified with him, ${ }^{10}$ it is perhaps understandable that Wiedmann chose instead to allow his opening movement, also identified as a concert, to precede the sermon in the traditional, non-liturgical sense.

9 Among the composers listed in RISM who are known to have written three compositions for one funeral are Samuel Fix (F1099), Johann Michael Jacobi (J207), Jeremias Koch (K1062), Heinrich Schwemmer (S2491, S2504, S2514) and Leonhard Sturm (S7085). Composers identified in W. Reich's Threnodiae Sacrae: Katalog der gedruckten Kompositionen des 16.-18. Jahrhunderts in Leichenpredigtensammlungen innerhalbderDeutschen Demokratischen Republik (Dresden: Veröffentlichung der Sächsischen Landesbibliothek, 1966) include Paul Lutkeman (No. 396), Heinrich Schwemmer (Nos.325, 329, 412), Johann Stolle (No. 136), and Eusebius Vitus (No.409).

10 See G. S. Johnston, “Textual Symmetries and the Origins of Heinrich Schütz's Musikalische Exequien," Early Music 19, no. 2 (May 1991): 213-25. 
The placement of the second and third movements, on the other hand, deserves closer attention. In the case of Schütz's Exequien, it would have been customary for the service to draw to a close with a Collect and Benediction after the performance of the eight-voice polychoral motet setting of "Herr, wenn ich nur dich habe" (Psalm 73:25-26), which was sung after the sermon. Rather than following this familiar route, the choir, evidently with little or no pause, ${ }^{11}$ commenced with the third-movement setting of "Herr nun lässest du deinen Diener in Frieden fahren" (Luke 2:29-32). Likewise with Wiedemann, and no less extraordinary, the second movement performed after the sermon proceeds, without pause, directly into the third movement, a setting of Luther's translation of the Latin Consummatum est, "Es ist vollbracht" (John 19:30). ${ }^{12}$

In addition to the similarities in the number of component parts, their placement within the ceremony, and the unusual transition from the second to the third movements, there are certain features within individual movements that would suggest more than a coincidental resemblance between the two compositions. In looking at the two composers' treatment of the first movements, we must bear in mind that certain elements of style and musical language will have changed considerably in the fifty-eight years separating the two compositions. For instance, Schütz's modal work is strictly for voices with basso continuo, ${ }^{14}$ whereas Wiedemann's tonal work also includes an array of stringed and wind instruments, a feature more consistent with concerto and cantata composition of the late seventeenth century. What is most striking is the two composers' use of alternating biblical and chorale texts. While the simultaneous singing of two different texts was not uncommon in German music of the Renaissance and Baroque, the technique of alternating biblical and chorale verses within a single work was apparently first practised by Schütz in the opening movement of the Musikalische Exequien. ${ }^{14}$ The impulse for Schütz's writing in this way, of

11 According to Christoph Richter's Abdruck / Derer Sprüche Göttlicher Schrifft vnd Christlicher Kirchen Gesänge (Gera, 1636), written as a record of the ceremony and appended to the Leichenpredigt, the motet setting of the sermonic theme was sung "Nach der Predigt" and "Folgendsdarauff das Canticum Simeonis, Luc. 2." The Abdruck, catalogued as Stolberg Leichenpredigtensammlung Nr. 18709, ff. 43r-48r, is reproduced in facsimile in Graulich, "Kritischer Bericht," xlvi-1.

12 All three vocal groups share the text of the fifth verse in the second concert, which concludes "Daß ich mag frölich singen das Consummatum est" (That I might joyously sing the Consummatum est).

13 The possibility of instrumental participation in performances of the Musikalische Exequien is discussed by G. Graulich, K. Hofmann, and P. Horn in the Preface to H.Schuitz, Musikalische Exequien, xi-xiii (Engl. trans., xxviii-xxix).

14 F. Krummacher, Die Choralbearbeitung in der protestantische Figuralmusik zwischen Praetorius und Bach. Kieler Schriften zur Musikwissenschaft, v. 22 (Kassel:Bärenreiter, 1978), 2. 
course, was to satisfy Heinrich Posthumus's wish to have all thirteen scriptural and eight biblical verses inscribed on his coffin treated in a single work. The practice of alternating between scriptural and chorale verses subsequently became increasingly popular among German composers in the second half of the century - notably in the works of Andreas Hammerschmidt and Wolfgang Carl Briegel - and is clearly evident in the opening concert of Wiedemann's funeral music, where four scriptural verses alternate with verses from three different chorales. $^{15}$

The second movements in both Schütz's and Wiedemann's works are settings of the sermonic motto, and both are composed on a significantly larger scale than the first. Schütz's setting of "Herr, wenn ich nur dich habe" is for two four-voice choirs (CATB, CATB). Wiedemann's is even more elaborate, written for three separate choirs: the first for ATB and two flutes, the second for SI-II and three viole da gamba, and the third for solo soprano and accompanying lutanist. Wiedemann's work is also more elaborate textually than the Exequien, continuing the pattern of alternating texts established in the first movement. While the first choir sings four Old and New Testament texts, the second choir is based on the sermonic motto "Ich werde nicht sterben, sondern leben" (Psalm 118:17), and the soloist sings the chorale text "Herzlich thut mich verlangen." Although the treatment of texts and musical styles differs here, there are still significant comparisons that can be drawn between the two. First, there is in each instance a noteworthy shift from a single choir in the first movement to multiple choirs in the second. Also, the second movement in each case carries the sermonic motto. Thus, while the two works in themselves would not be considered unusual as independent funerary motets, they acquire significance in the present context because they share certain qualities and because of their placement as the second item in an unusual grouping of three funerary compositions.

The third movements once again display some striking similarities. First of all, both composers employ two separate performing groups. In Schütz's Exequien, the Chorus Primus is scored for (Semi)CATTB, the Chorus Secundus for two sopranos and a baritone. The concluding Beschluß-Liedgen that concludes

Also by F. Krummacher, Die Überlieferung der Choralbearbeitungen in der frühen evangelischen Kantate; Untersuchungen zum Handschriftenrepertoire evangelischer Figuralmusik im späten 17. und beginnden den 18. Jahrhundert, Berliner Studien zur Musikwissenschaft: Veröffentlichungen des Musikwissenschaftlichen Instituts der Freien Universität Berlin, vol. 10 , ed. Adam Adrio (Berlin: Merseburger, 1965).

15 Two of the three chorales used by Wiedemann, though certainly by coincidence, were also used by Schütz. I am grateful to Friedhelm Krummacher for providing me with additional information on this kind of Choraltropierung in the second half of the seventeenth century. 
Canto Solo

Laute

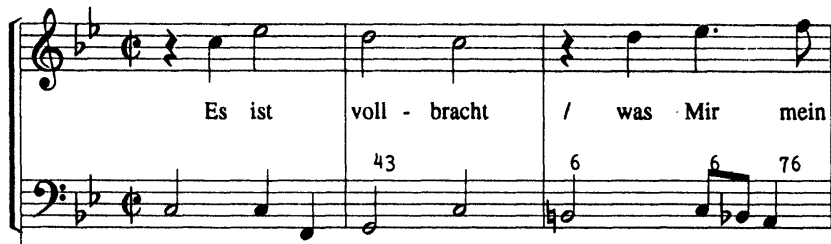

Canto I

Canto II

Alto

Tenore

Basso

Organo

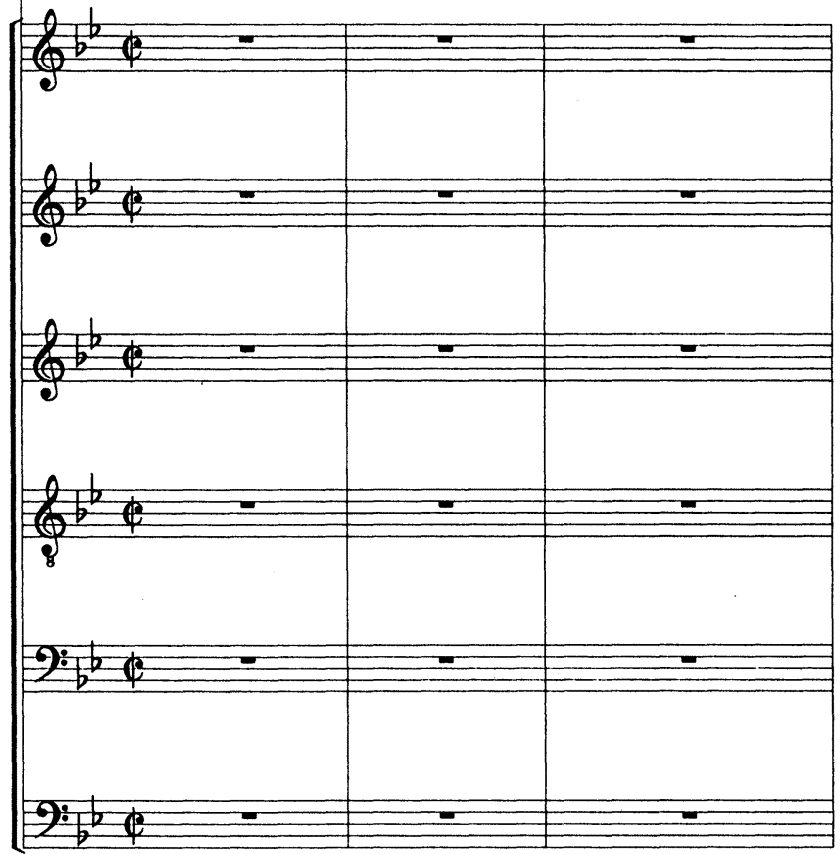

Example 1: M. Wiedemann, Kurtzes Beschluß-Liedgen auf das Consummatum est, mm. 1-3.

Wiedemann's triptych is likewise scored for one large vocal ensemble (CCATB) and a smaller performing group comprising, as in the preceding movement, a solo soprano and lutanist (see example 1).

Secondly, the principal text used by Schütz is the Canticle of Simeon (Luke 2:29-32), "Herr, nun lässest du deinen Diener in Frieden fahren" (Lord, now lettest thou thy servant depart in peace), the German translation of the traditional Nunc Dimittis. According to Scripture, Simeon, who came to know through the 


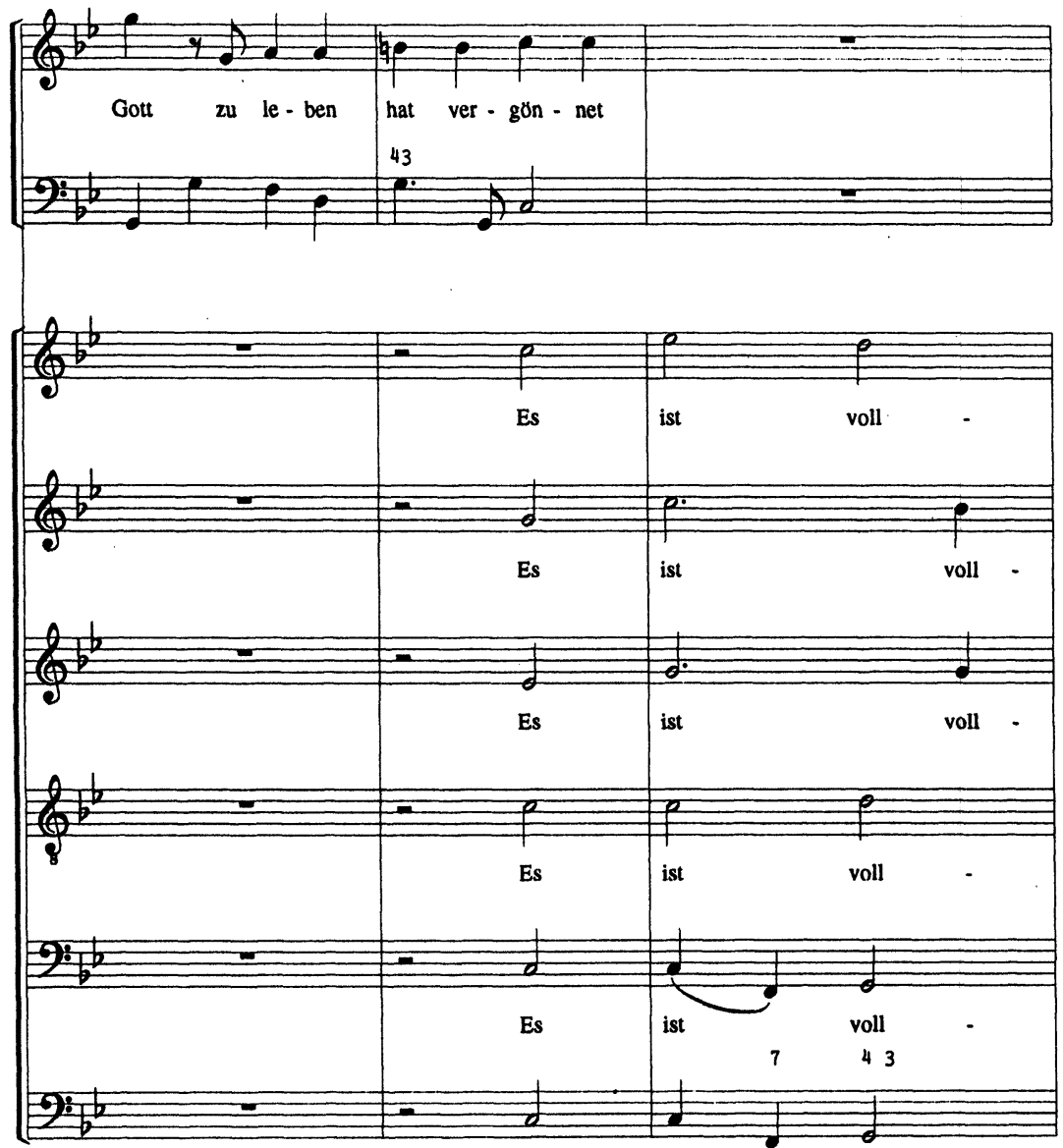

Example 1, mm. 4-6.

Holy Spirit that he would not die until he had seen the Lord's Messiah, sang this canticle upon seeing the child Jesus in the temple at Jerusalem. Wiedemann bases his work on the obvious alternative, the German translation of the Latin Consummatum est (John 19:30), "Es ist vollbracht" (It is finished). These, of course, were the last words uttered by the crucified Christ when he, like Simeon, was at last prepared to surrender his spirit.

Third and most striking about the concluding movements is the fact that both composers take pains to personify the deceased musically. While the textual and musical personification of the dead was not uncommon in seventeenth-century 

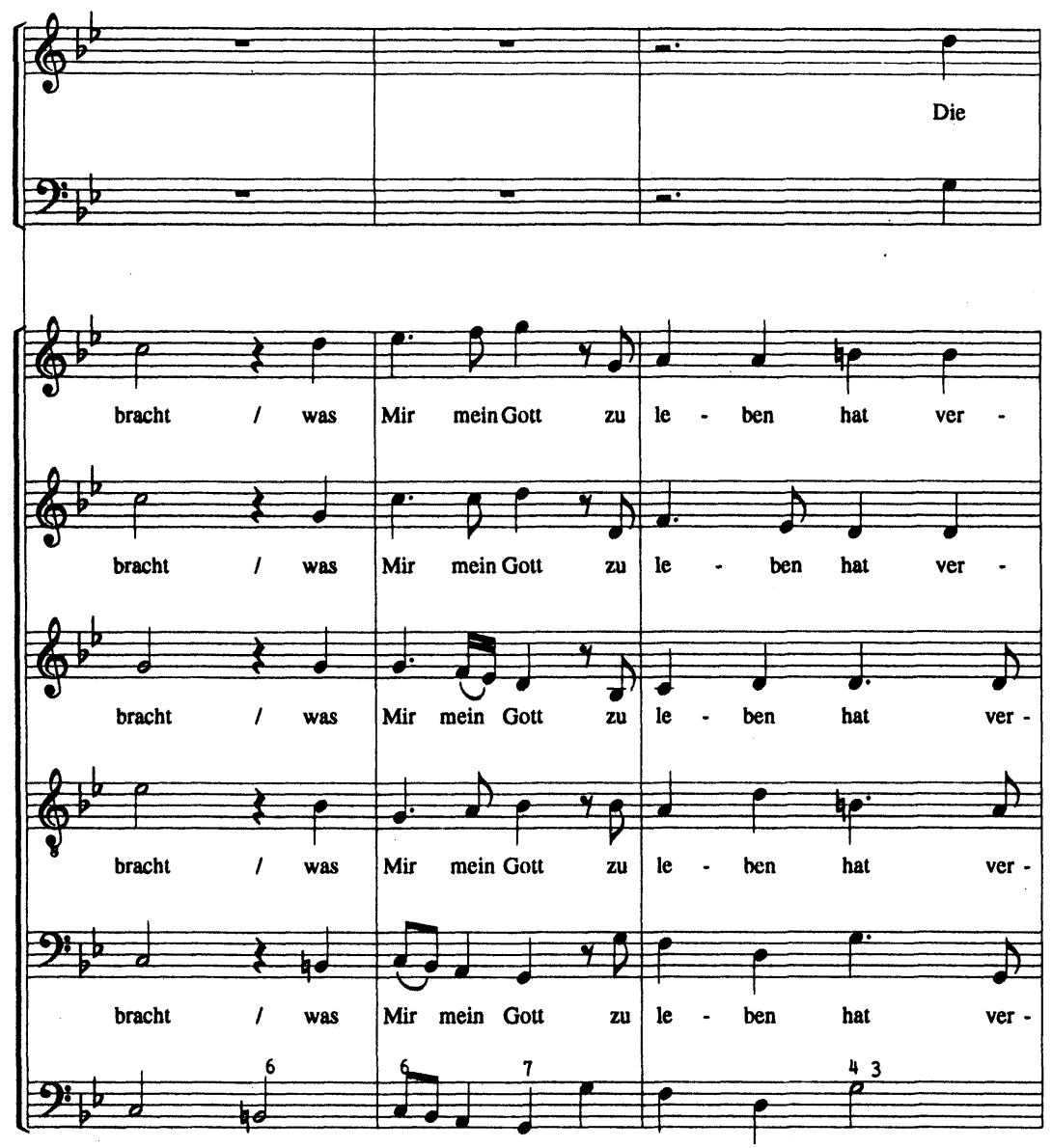

Example 1, mm. 7-9.

German funeral music, no other composer went to the extremes of Schütz and Wiedemann. ${ }^{16}$ In the case of Schütz, Prince Heinrich Posthumus is portrayed by the Baritone in the small three-voiced Chorus Secundus. The two sopranos in this

16 The concept of personification in seventeenth-century German funeral music is dealt with in my articles, "Rhetorical Personification of the Dead in Seventeenth-Century German Funeral Music: Heinrich Schütz's Musikalische Exequien (1636) and Three Works by Michael Wiedemann (1693)," Journal of Musicology 9, no. 2 (Spring 1991): 186-213; and more generally in "Musical-rhetorical Prosopopoeia and the Animation of the Dead in Seventeenth-Century German Funeral Music," Canadian University Music Review 10, no. 1 (1990): 12-39. 


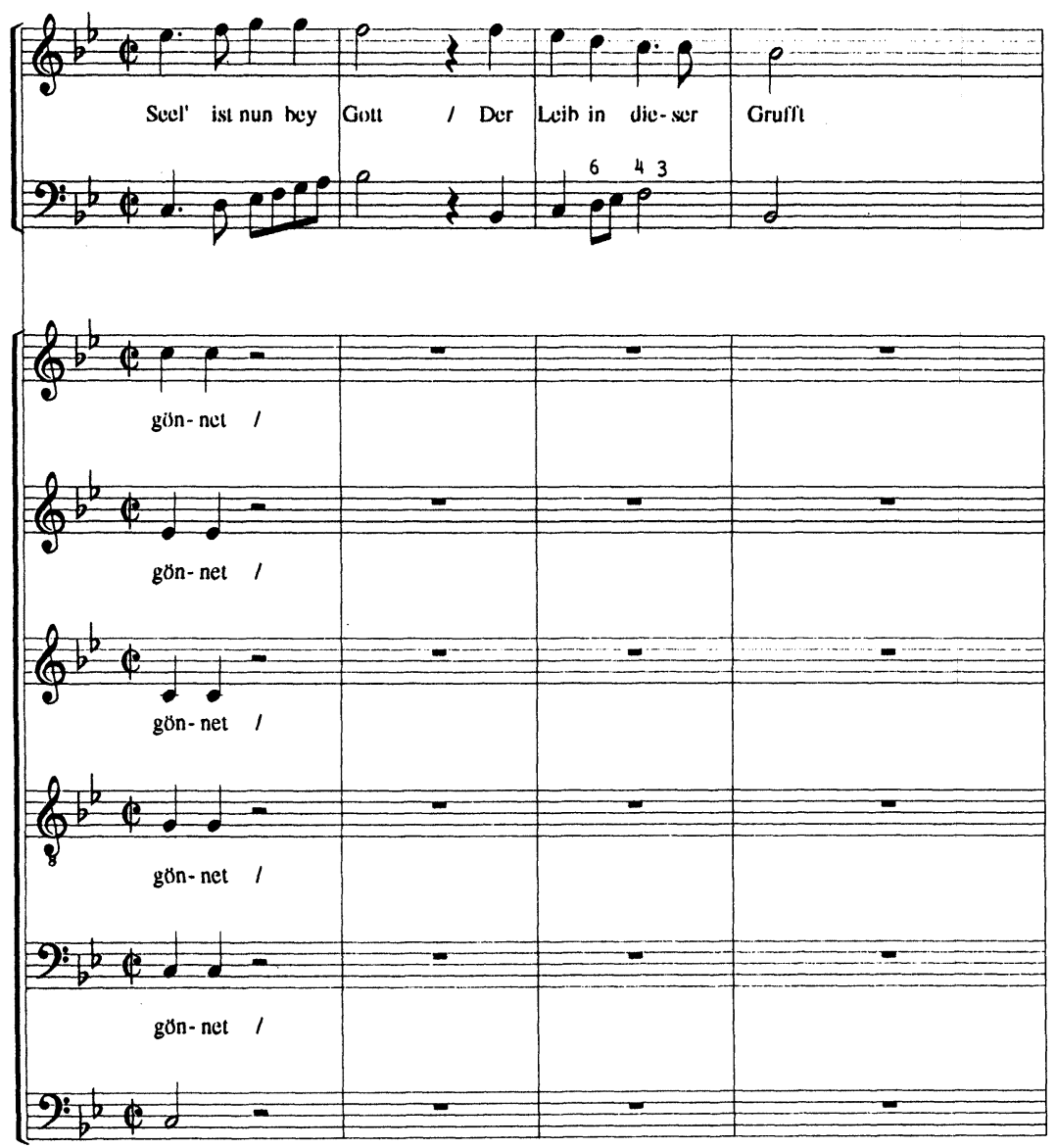

Example 1, mm. 10-13.

concertato choir are labelled Seraphim I and II by Schütz. While the larger Chorus Primus was to perform near the organ, the concertato Chorus Secundus was stationed in the distance ("in die Ferne geordnet"), most likely hidden from the view of the congregation, an effective dramatic device used by Schütz to enhance the personification of biblical figures in the Historia der frölichen vnd siegreichen Aufferstehung vnsers einigen Erlösers vnd Seligmachers Jesu Christi... of $1623 .{ }^{17}$ In the course of the movement, the choirs sing in alternation

17 H. Schütz, "Preface to Historia der Aufferstehung Jesu Christi," in Readings in the History of Music in Performance, trans. and ed. C. MacClintock (Bloomington: Indiana University Press, 
or succession, portraying, as Schütz writes, "the joy of the blessed disembodied Soul in Heaven in the company of Heavenly Spirits and holy Angels". ${ }^{18}$ Wiedemann's work is no less striking in assigning a physical dimension through the spatial deployment of the personifying voice. Whereas Schütz had identified the personified Prince as the "Beata anima cum Seraphinis" (Blessed spirit with the seraphim), Wiedemann portrays the personified Baron as the "Seelen Stimme" (Voice of the Soul). Where Schütz placed the deceased in the company of two angels (represented by two sopranos), Wiedemann likewise imparted a more heavenly tone by specifying in the score that the Voice of the Soul was to be accompanied by a lute - intended most likely to evoke in the mind of the listener the popular image in Renaissance and Baroque paintings of angel consorts. Corresponding to Schütz's directives in the last movement of having the Chorus Secundus perform in the distance are Wiedemann's own exacting instructions for the Seelen Stimme and lutanist likewise to perform from a remote, concealed position in the Baron's family vault ("... in der Grufft verdecket").

Although we are missing the piece of hard evidence that would demonstrate absolutely that Wiedemann based his music on Schütz's Musikalische Exequien, there is ample circumstantial evidence to prompt us to accept Schütz as a probable model. To summarize briefly, both works are among the very few concerted works of the dozen or so published funerary works of the seventeenth century to be composed in three discrete parts. The first movements are somewhat novel in that the texts consist of alternating biblical and chorale verses. The second are comparable in that both are polychoral (in contrast to the first movement) and consist of settings of the sermonic motto. The second movements, with seemingly little or no break, are followed by the third. And the third movements are highly unusual in that they are based on the two biblical texts which epitomize the resignation of the spirit; personify the deceased textually, musically and spatially; evoke an epiphanic vision through the accompanying heavenly voices or instrument; and conceal from view the musicians personifying the deceased.

Why would Wiedemann, in 1693, use Schütz as a model? There are a number of plausible reasons. It was common practice throughout the Baroque for composers to borrow musical ideas from one another. In fact, we see from the

1979), 142. In his preface to the Historia, Schütz writes: "It should be kept in mind that this History will be performed with better grace or effect if only the Evangelist is seen, the other personages and others remaining hidden."

18 Graulich, lxii. “... die Freude der abgeleibten Sehligen Seelen im Himmel / in Gesellschafft der Himmlischen Geister vnd heiligen Engel ..." English trans. in Graulich, xl. 
earliest baroque treatises on composition onward, as in the manuals written by Joachim Burmeister between 1599 and $1606,{ }^{19}$ that the practice of rhetorical imitatio, draping one's own compositions on the general scaffolding of a superior composer, was one of the principal means by which the novice learned his craft and mastered his art. Just as Wiedemann as a pastor would have learned the rhetoric of sermonic oratory of the Lutheran Church by analyzing and imitating some of the thousands of sermons published in the seventeenth century, ${ }^{20}$ he as a composer would have acquired his knowledge of musical rhetoric by studying and emulating the best composers of his and earlier generations.

More specific to the occasion, one should also bear in mind the fact that Wiedemann was not primarily a composer by profession, let alone a composer accustomed to writing large-scale concerted works such as the ones he undertook to write for Sigismund Heinrich. He was known principally as a cleric, theologian and poet, and his other surviving musical works are modest Gesänge for one to three voices. For Wiedemann, Sigismund Heinrich's death probably signified one of the most important moments in his career, since as pastor he was responsible for writing the more than one hundred pages of funeral sermon, and possibly as well other parts of the published Leichenpredigt which included, among other things, another funerary oration, the Baron's curriculum vitae, and assorted poetry - this in addition to the seventy pages of music he composed. The arrangements for the ceremony itself no doubt occupied some of his time as well, and he would of course have had to continue during this time to perform his regular pastoral duties at the court. It therefore would not be surprising for Wiedemann, as an amateur composer under considerable pressure, to look for a suitable model. Schütz would have been an obvious choice, since he was recognized throughout the seventeenth century as the most important and influential composer of Lutheran Church music and was still highly esteemed by German musicians at the end of the century. ${ }^{21}$ The Musikalische Exequien would

19 Musical-rhetorical imitatio of this kind is discussed by Burmeister under the heading "Accessio prima" in Musica autoschediastike (Rostock, 1601) and as Chapter 16 (De imitatione) of Musica poetica (Rostock, 1606). See M. Ruhnke, Joachim Burmeister: ein Beitrag zur Musiklehre um 1600 (Kassel: Bärenreiter Verlag, 1955), 55-56, 106-8, 166-69. See also C. Palisca "Ut Oratoria Musica: The Rhetorical Basis of Musical Mannerism," in The Meaning of Mannerism, ed. by F.W. Robinson and S.G. Nichols, Jr. (Hanover, New Hampshire: University Press of New England, 1972), 37-65.

20 Books such as Christoph Weißenborn's Politischer Leich=Redner (Jena: Heinrich Christoph Cröker, 1707) were written and published expressly for the purpose of teaching funerary oratory.

21 W. C. Printz, Historische Beschreibung der edlen Sing- und Klingkunst ... aus den vornehmsten autoribus abgefasst und in Ordnung gebracht, facsimile reprint ed. O.Wessely, Die grossen Darstellungen der Musikgeschichte in Barock und Aufklärung, vol. 1 (Dresden, 1690; Graz: Akademische Druck-u. Verlagsanstalt, 1964), 136-37. 
have been attractive to Wiedemann partly because of the sheer beauty of it and partly because of the similarities of the occasion - that is, a Lutheran funeral service for the head of a noble household. Certainly a funeral cantata would have been more fashionable at this late date, 1693 , but Wiedemann would not have had much access to model compositions since the scores or parts for ad hoc funeral cantatas were seldom published at that time. ${ }^{22}$

Precisely how Wiedemann would have come across Schütz's Musikalische Exequien is difficult to say. In 1693, Wiedemann was employed by Sigismund Heinrich at Ossig, a scant eighty kilometres (fifty miles) east of Dresden, from which cultural centre Schütz's reputation spread throughout much of Europe and where in fact the Exequien had been published. Even though the publishing run for the Exequien was likely quite small, there is a very good chance that a print or copy of the work would have found its way to Ossig, falling eventually into the hands of Wiedeman. ${ }^{23}$

My aim in this study has been to postulate Heinrich Schütz's Musikalische Exequien as a probable compositional model for three funerary works by Michael Wiedemann, based on comparisons of the similar circumstances which occasioned the compositions, on the identification of certain shared compositional procedures exclusive to these works, on possible professional motivations for Wiedemann's having used Schütz as a model, and, to some extent, on the logistics of publishing and geography which would have made the Exequien available to Wiedemann. While caution must be exercised in positing this relationship between the two works, one must be no less cautious when concluding, as others have, that a work such as the Musikalische Exequien is without resonance if the assumption is based solely on surviving period documents. In dealing with this repertoire one must bear in mind the severe rate of attrition sustained by prints and manuscripts over the last 350 years - even more so when they originate in an era when compositions were not habitually saved for posterity and in a land which has suffered more than most the ravages of time. The manuscript copy of the continuo part for the third movement of Schütz's Exequien and the organ tablature of the first two movements mentioned earlier in this paper have themselves survived against staggering odds. Similarly, of a minimum publishing run of perhaps 75 to 100 copies of Wiedemann's music for Sigismund Heinrich, two complete prints survive - and these only because they happened to find their way into anthologies of funeral sermons (Leichen-

22 W. Reich, "Die deutschen gedruckten Leichenpredigten des 17. Jahrhunderts als musikalische Quelle," Ph.D. dissertation (Karl Marx University, 1962), 162, 172.

23 By comparison, Johannes Šimbracky, who made the intabulation of the Musikalische Exequien, was employed more than $\mathbf{5 0 0}$ kilometres away from Dresden. Gdansk, where the copy of the basso continuo part of the Exequien is found, is also well in excess of $\mathbf{5 0 0}$ kilometres from Dresden. 
predigtensammlungen) ${ }^{24}$ If that one page of continuo in Gdansk had gone the way of the remaining continuo and vocal parts, if Šmbrackýs organ tablature had been simply discarded after the performance in 1645, if Wiedemann's music had been excised from the anthology and lost (as was frequently the case with this repertoire) or only partly preserved, we would have no evidence at all of the Exequien's influence. Even if one percent or less of the prints, copies, transcriptions and imitations has survived the seventeenth century, we should still be able to suggest with reason that Schütz's Musikalische Exequien - however modestly -attracted more interest and enjoyed greater popularity than modern scholarship has hitherto permitted.

\begin{abstract}
Heinrich Schütz's Musikalsche Exequien (SWV 279-81), written for the funeral of Prince Heinrich Posthumus von Reuß in 1636, is generally regarded as one of his finest works. Oddly, though, the praise accorded the composition has come almost entirely from critics of the last fifty years, while it is thought to have had negligible resonance in the seventeenth century. The present article suggests that the Exequien may in fact have been used as a model for three compositions by Michael Wiedemann in 1693. Based on comparisons of the circumstances which occasioned the works, on the identification of numerous shared compositional processes exclusive to these works in the seventeenthcentury funerary repertory, on certain professional motivations, and on the logistics of publishing and geography which would have made the Exequien available to Wiedemann, it becomes possible to suggest with reason that Schütz's Musikalische Exequien was not without influence in baroque Germany.
\end{abstract}

24 In each case where Wiedemann's music for Sigismund Heinrich survives, the print is appended to the Baron's Leichenpredigt, preserved in a volume of published Leichenpredigten. Wolfgang Reich mentions a copy of Sigismund Heinrich's Leichenpredigt as part of the Stolberg-Stolberg Leichenpredigtensammlung currently housed in the Herzog-August-Bibliothek in Wolfenbüttel; in this instance, the music was removed and subsequently lost. Reich, Threnodiae Sacrae, 27. 